\title{
Leprosy: review of the epidemiological, clinical, and etiopathogenic aspects - Part $1^{*}$
}

\author{
Joel Carlos Lastória ${ }^{1}$
}

\author{
Marilda Aparecida Milanez Morgado de Abreu
}

\section{DOI: http://dx.doi.org/10.1590/abd1806-4841.20142450}

\begin{abstract}
Leprosy is caused by Mycobacterium leprae and has been known since biblical times. It is still endemic in many regions of the world and a public health problem in Brazil. The prevalence rate in 2011 reached 1.54 cases per 10,000 inhabitants in Brazil. The mechanism of transmission of leprosy consists of prolonged close contact between susceptible and genetically predisposed individuals and untreated multibacillary patients. Transmission occurs through inhalation of bacilli present in upper airway secretion. The nasal mucosa is the main entry or exit route of M. leprae. The deeper understanding of the structural and biological characteristics of M. leprae, the sequencing of its genome, along with the advances in understanding the mechanisms of host immune response against the bacilli, dependent on genetic susceptibility, have contributed to the understanding of the pathogenesis, variations in the clinical characteristics, and progression of the disease. This article aims to update dermatologist on epidemiological, clinical, and etiopathogenic leprosy aspects.
\end{abstract}

Keywords: Classification; Clinical diagnosis; Disease transmission, infectious; Education, continuing; Epidemiology; Genetic phenomena; Immunologic factors; Leprosy; Mycobacterium leprae; Signs and symptoms

\section{INTRODUCTION}

Leprosy is a chronic infectious disease caused by Mycobacterium leprae. It is highly contagious, but its morbidity is low because a large portion of the population is naturally resistant to this disease. Leprosy affects mainly the skin and peripheral nerves. Its diagnosis is established based on skin and neurologic examination of the patient. Early diagnosis is very important. The timely and proper implementation of treatment will prevent sequelae and physical disabilities that have an impact on the individual's social and working life, which are also responsible for the stigma and prejudice regarding this disease.

\section{HISTORY}

This disease has been known as leprosy since the biblical times, with reports of cases dating over 3000 years ago. There are doubts whether leprosy originated in Asia or Africa. The term Leprosy is a tribute to the Norwegian physician Gerhard Armauer Hansen, who identified the bacillus Mycobacterium leprae as the cause of the disease in $1873 .{ }^{1}$
Leprosy is believed to have been introduced in Europe from India by the troops of Alexander, the Great, 300 BC. Its incidence was high in Europe and the Middle East during the Middle Ages. The number of cases was dramatically reduced around 1870 because of the socioeconomic development. Leprosy is assumed to have been introduced in Latin America during the colonization period by French people in the United States and by Spanish and Portuguese people in South America. African slave traffic was the major cause of the spread of leprosy in the Americas. The first cases were reported in Brazil in 1600 in the city of Rio de Janeiro. The first isolation hospital was installed in Rio de Janeiro. After that, the disease spread to the other Brazilian regions. ${ }^{1}$

The main strategy used to prevent the spread of leprosy in the past was the compulsory isolation of patients in leper colonies, which were established in Brazil in 1923. With the introduction of sulfone in the 1940s and its use in the treatment of leprosy due to its effectiveness, isolation was no longer mandatory; however, it was only officially abolished in 1962.

Received on 16.01.2013

Approved by the Advisory Board and accepted for publication on 21.03.2013

* Work conducted at Universidade Estadual Paulista (UNESP); Hospital Regional de Presidente Prudente - Universidade do Oeste Paulista (HRPP- UNOESTE) - Presidente Prudente (SP), Brazil.

Financial Support: None.

Conflict of Interest: None.

Faculdade de Medicina de Botucatu - Universidade Estadual Paulista "Júlio de Mesquita Filho" (FMB-UNESP) - Botucatu (SP), Brazil.

Hospital Regional de Presidente Prudente - Universidade do Oeste Paulista (HRPP-UNOESTE) - Presidente Prudente (SP), Brazil

(C)2014 by Anais Brasileiros de Dermatologia 
Nevertheless, until the mid-1980s, many patients still remained isolated for several reasons. Because of cases of resistance to sulfone monotherapy in 1970, the World Health Organization (WHO) suggested the use of multidrug regimens. Therefore, since the early 1980s, the disease has been treated with multidrug regimens in outpatient settings and patients are considered cured after treatment. However, multidrug therapy (MDT) was only extensively and officially implemented in Brazil in 1993.,

The term hanseniasis was proposed to reduce the stigma associated with the disease in 1967 by Professor Abraão Rotberg. The term was officially adopted in Brazil in 1970, becoming mandatory according to the federal law no. 9010 effective as of March 29, 1995. ${ }^{4}$

\section{EPIDEMIOLOGY}

Leprosy is endemic in tropical countries, especially in underdeveloped or developing countries. Its prevalence has decreased markedly since the introduction of MDT in the beginning of the 1980s. However, 105 endemic countries, specifically located in Southeast Asia, in the Americas, Africa, Eastern Pacific and Western Mediterranean, still concentrate a large number of cases. In 2011, 219,075 new cases were detected in the world. In the first quarter of 2012, 181,941 new cases were recorded and there was a prevalence of 0.34 cases per 10,000 inhabitants. ${ }^{5}$

Brazil has not achieved the goal of elimination of leprosy as a public health problem (defined by the prevalence lower than 1 case per 10,000 inhabitants), ranking second in terms of absolute number of cases, with India being the first in the ranking. ${ }^{6}$ Brazil has a prevalence rate of 1.54 cases per 10,000 inhabitants, with 33,955 new cases in 2011, 61\% of which were multibacillary (MB). The disease is unevenly spread through the different regions of the country, with the following prevalence rates per 10,000 inhabitants: 3.75 in the Midwest, 3.49 in the North, 2.35 in the Northeast, 0.61 in the Southeast, and 0.44 in the South. The main epidemiological indicators used in Brazil are the detection rate of new cases, the rate of new cases in children younger than 15 years old, the cases with grade- 2 disability. ${ }^{8}$

Epidemiological data from some countries, including India, should be interpreted with caution, because the goals of disease elimination were achieved based on some criteria, such as: changes in the definition of case, exclusion of recurrent cases from the prevalence rate, exclusion of cases of treatment dropout from active records, single-dose treatment of paucibacillary (PB) patients, shorter duration of treatment, etc. This caused a sharp drop in the number of new cases reported. ${ }^{9}$ In Brazil, the prevalence of leprosy has declined significantly since 2000; detection rates have been falling, although gradually probably as a consequence of broader patient access to primary care. ${ }^{10}$

The reduction of cases of leprosy in children under 15 years old is a priority in Brazil, because this is the main endemic monitoring indicator. Cases in this age group suggest recent transmission with active infection focus and high endemic area, revealing operational deficiency. An analysis of the people the patient had contact with is likely to find the source of the infection, as this source usually is close. The peak detection of cases in people under 15 years old occurred in 2003, when 4,181 cases were detected, resulting in a detection coefficient of 7.98 per 100,000 inhabitants. Thereafter, the rates have been falling; in 2011, 2,420 new cases were detected, resulting in a detection coefficient of 5.22 per 100,000 inhabitants. ${ }^{11}$

The population's lack of knowledge about the disease and the patients' difficulty to have access to specific treatment in some regions contribute to the late diagnosis of leprosy. This may result in physical disability, an indicator used to measure the quality of services. Although the progressive reduction of physical disability in leprosy cases because of the current larger number of early diagnosis in the country, 2,165 cases had grade-2 disability in $2011 .{ }^{6}$ A possible explanation for this might be the hidden prevalence of leprosy; that is, a reservoir of undetected cases influenced by epidemiological and operational elements that preserves sources of infection. ., $12-14^{-14}$

The strategy used for disease control by the Coordination for leprosy and Diseases under Elimination of the Health Surveillance Secretariat of the Ministry of Health consists in early detection and prompt treatment of cases to eliminate the sources of infection and prevent sequelae. Integrated services and partnerships support the actions for disease control. ${ }^{6}$

\section{ETIOPATHOGENESIS}

\section{Etiologic agent}

The etiologic agent, M. leprae, was identified by Norwegian physician Gerhard Armauer Hansen in 1873. Therefore, it is also called Hansen's bacillus.

Taxonomy, morphology, staining and biological characteristics of $M$. leprae

M. leprae's scientific classification is as follows: class Schizomycetes, order Actinomycetales, family Mycobacteriaceae, and genus Mycobacterium. M. leprae is a straight or slightly curved rod, with rounded ends, measuring 1.5-8 microns in length by 0.2-0.5 micron in diameter. In smears, it is red stained with fuchsin using the Ziehl-Neelsen $(\mathrm{ZN})$ stain, and because of its high lipid content, it does not get discolored when washed with alcohol and acid, thus showing the characteristics of acid-alcohol-resistant bacil- 
li (AARB). M. leprae is different from other mycobacteria in terms of arrangement, since it is arranged in parallel chains, just like cigarettes in a pack, bound together forming the globi. When the Gram staining method is used, $M$. leprae is gram-invisible, appearing as negatively stained images, called ghosts, or as bead-like gram-positive bacilli. 15,16

$M$. leprae infects mainly macrophages and Schwann cells. It has never been grown in artificial media. Reproduction occurs by binary fission and it grows slowly (about 12-14 days) in the foot pads of mice. The temperature required for survival and proliferation is between $27^{\circ} \mathrm{C}$ and $30^{\circ} \mathrm{C}$. This explains its higher incidence in surface areas, such as skin, peripheral nerves, testicles, and upper airways, and lower visceral involvement. $M$. leprae remains viable for 9 days in the environment. ${ }^{15-19}$

\section{Ultrastructural characteristics of $M$. leprae}

The ultrastructure of $M$. leprae is common in the genus Mycobacterium. Electron microscopy has shown that this bacillus has cytoplasm, plasma membrane, cell wall, and capsule. The cytoplasm contains common structures in gram-positive microorganisms. The plasma membrane has a permeable lipid bilayer containing interaction proteins, which are the protein surface antigens. The cell wall attached to the plasma membrane is composed of peptidoglycans bound to branched chain polysaccharides, consisting of arabinogalactans, which support mycolic acids, and lipoarabinomannan (LAM), similarly to other mycobacteria. The capsule, the outermost structure, has lipids, especially phthiocerol dimycocerosate and phenolic glycolipid (PGL-1), which has a trisaccharide bound to lipids by a molecule of phenol. This trisaccharide is antigenically specific for M. leprae..$^{20,21}$

\section{The genome of $M$. leprae}

The genome of $M$. leprae was sequenced by Cole et al. in $2001 .^{22}$ It is circular. Its estimated molecular weight is $2.2 \times 109$ daltons, with 3,268,203 base pairs (bp) and guanine + cytosine content of $57.8 \%$. When compared to the genome of Mycobacterium tuberculosis, which has $4,411,529$ bp and guanine + cytosine content of $65.6 \%$, it seems that $M$. leprae underwent reductive evolution, resulting in a smaller genome rich in inactive or entirely deleted genes. It has 2,770 genes, with coding percentage of $49.5 \%$, that is, 1,604 genes encoding proteins $(1,439$ genes common to $M$. leprae and M. tuberculosis) and 1,116 $(27 \%)$ pseudogenes. The latter are randomly distributed in the genome and may correspond to regulatory sequences or residual gene mutations that become unrecognizable. These characteristics cause significant reduction of metabolic pathways, thus explaining why the bacillus requires specific conditions to grow..$^{2,23}$

\section{Reservoirs of M. leprae}

Human beings are the reservoir of $M$. leprae, but animals, such as armadillos, chimps, and other apes, the soil, water, and some arthropods are natural reported reservoirs. ${ }^{24-29}$

\section{Mechanisms of leprosy transmission}

It is believed that leprosy transmission occurs by close and prolonged contact between a susceptible individual and a bacillus-infected patient through inhalation of the bacilli contained in nasal secretion or Flügge droplets. The main route of transmission is the nasal mucosa. ${ }^{30-32}$ Less commonly, transmission can occur by skin erosions. ${ }^{32,33}$ Other transmission routes, such as blood, vertical transmission, breast milk, and insect bites, are also possible..$^{29,34-36}$

It is assumed that infected individuals, even those who did not develop the disease, may have a transitional period of nasal release of bacilli. ${ }^{37-40}$ The presence of specific DNA sequences $M$. leprae in swabs or nasal biopsies and seropositivity for specific bacillus antigens in healthy individuals living in endemic areas suggest the carrier plays a role in the transmission of leprosy. ${ }^{37,38,41-51}$

\section{Genetic factors}

Although the exact genes involved in leprosy are not known, it is accepted that different sets of genes of the human leukocyte antigen system (HLA) and non-HLA have an impact on the susceptibility to leprosy, both in infection per se control and in the definition of the clinical presentation. Changes in candidate genes, that is, genes whose product participates in the host response to the infectious agent, have been currently investigated. Genomic scan studies identified binding peaks for leprosy in chromosome regions 6p21, 17q22, 20p13, and 10p13. ${ }^{52,53}$

MRC1 gene markers located in the $10 \mathrm{p} 13$ region are associated with leprosy per se. ${ }^{53}$ Analysis of the polymorphisms of exon 7 of the MRC1 gene, which encodes receptors expressed in macrophages and dendritic cells and are involved in innate immune responses, showed that the G396-A399-F407 haplotype is associated with leprosy per se and the multibacillary (MB) forms. ${ }^{53}$ Variations in the PARK2 and PARCRG genes are also associated with the control of susceptibility to leprosy per se because they change the response of the macrophages to M. leprae. ${ }^{54}$ The LTA+80 single nucleotide polymorphism is related to increased risk of leprosy in young populations because it reduces the expression of lymphotoxin alpha (LTA), a cytokine of the tumor necrosis factor (TNF) superfamily that participates in the activation of lymphocytes and is encoded by the LTA gene. ${ }^{55}$ Polymorphisms in the promoters of the genes for tumor necrosis factor- 
alpha (TNF- $\alpha$ ) and interleukin-10 (IL-10) are associated with the development of leprosy, particularly $\mathrm{MB}$ disease, in the polymorphism in the promoter for TNF- $\alpha .^{56,57}$ Analyses using single nucleotide polymorphisms located in the promoter region of the IL-10 gene revealed that the $-819 \mathrm{~T}$ allele is associated with susceptibility to leprosy. ${ }^{58-60}$ Conversely, it seems that the $-308 \mathrm{~A}$ allele of the promoter region of the TNF gene promotes protection against leprosy per se, in addition to regulating TNF production during reactions, with a higher frequency of neuritis in heterozygous patients. ${ }^{60-63}$ Recently, an association genome scan (Genome-Wide Association) for leprosy conducted in a Chinese population identified variations in seven genes (CCDC122, CD13orf31, NOD2, TNFSF15, HLA$D R, R I P K 2$, and LRRK2) associated with susceptibility to leprosy, with clearer findings for the CD13orf31, NOD2, RIPK2, and LRRK2 genes and MB leprosy. ${ }^{64}$ Currently, studies have tried to understand the binding effect observed between the chromosomal region 6q25-q27 and leprosy per se.

Polymorphisms in the promoter genes for TNF$\alpha$ and in the macrophage protein 1 associated with natural resistance (Nramp1) are associated with the development of MB leprosy. ${ }^{57,65}$ Evidence of association between chromosome region 10p13 and paucibacillary (PB) leprosy have been found. This finding has not been confirmed in later studies. ${ }^{66,53}$ Different alleles of the vitamin $\mathrm{D}$ receptor (VDR) gene are associated with tuberculoid and lepromatous leprosy. ${ }^{67}$ In the HLA complex region, there are links with genes of class II antigens, such as HLA DR2 and DR3 alleles associated with the tuberculoid form, and HLA DQ1 allele associated with the lepromatous form..$^{5,61}$

Variations in the TLR1 and TLR2 genes seem to be associated with the reversal reaction. No association has been demonstrated with the occurrence of neuritis or $\mathrm{ENH} .{ }^{68}$

\section{Immunopathology}

A wide variety of clinical and histopathological manifestations of leprosy occurs due to the ability of the host to develop different degrees of cellular immune response to $M$. leprae, which led to the spectral concept of the disease. ${ }^{69}$

The first barrier to infection with $M$. leprae is innate immunity, represented by the integrity of epithelia, secretions, and surface immunoglobulin A (IgA). In addition, natural killer (NK) cells, cytotoxic T lymphocytes, and activated macrophages can destroy bacilli, regardless of the activation of adaptive immunity. Effective innate immune response modulated by dendritic antigen-presenting cells, in combination with the low virulence of $M$. leprae, can be the basis for resistance to the development of clinical manifesta- tions of leprosy. After the infection is installed, the host immune response is still indefinite in the initial phase. Regulation of inflammatory cytokines and chemokines may lead to proliferation of T helper 1 (Th1) or Thelper 2 (Th2) lymphocytes, which will promote cellular or humoral immune response to $M$. leprae, respectively. This will determine the evolution of the disease to the tuberculoid or lepromatous form. ${ }^{70,71}$

In addition to being ineffective to prevent the development of the disease, the cellular immunity of the individuals who develop the tuberculoid form of the disease is exacerbated, being directly involved in the onset of skin lesions. The humoral immunity of the individuals who develop the lepromatous form of the disease, which is responsible for the production of IgM antibodies against PGL-1, does not offer protection, allowing bacillary dissemination. ${ }^{72,73}$

The in situ investigation of the phenotype of $\mathrm{T}$ lymphocytes using immunohistochemical techniques with monoclonal antibodies demonstrates a predominance of $\mathrm{T}$ helper (CD4+) in tuberculoid lesions, showing a CD4:CD8 ratio of 2:1, the same ratio found in blood, but with a memory:naive $\mathrm{T}$ cell ratio of $1: 1$ in the blood and 14:1 in the lesions; that is, CD4+ cells in tuberculoid lesions express the phenotype memory- $\mathrm{T}$ cells (CD45R0+). In lepromatous lesions, there is a predominance of the population of T CD8+ lymphocytes with $\mathrm{CD} 4: \mathrm{CD} 8$ ration of $0.6: 1$, regardless of blood ratio. In this lesions, half of the CD4+ cells belong to the subclass of T-naive cells, most CD8+ cells belong to the CD28- phenotype, suggesting that they are T-suppressor cells, whereas T-cytotoxic cells $(\mathrm{CD} 28+)$ predominates in tuberculoid lesions. ${ }^{70,71,74-77} \mathrm{It}$ has been observed that CD4+ cells (T memory phenotype) are bound to macrophages in the center of the tuberculoid granuloma and CD8+ cells are the cuff surrounding it. ${ }^{78}$ In the lepromatous granulomas, the CD8+ cells (T suppressor phenotype) are mixed with macrophages and CD4+ cells. ${ }^{79}$

The analysis of $\mathrm{T}$ cell clones of the lesions shows that different patterns of cytokines are produced by CD4+ and CD8+ subclasses. Clones of CD4+ cells from tuberculoid patients produce high levels of interferon-gamma (IFN- $\gamma$ ), interleukin-2 (IL-2), and TNF- $\alpha .{ }^{80-82}$ These clones were called T CD4+ cells, Th1 pattern, enhancers of cell-mediated immunity and reduced proliferation of $M$. leprae. Clones of CD8+ cells from lepromatous patients produce high levels of suppressor cytokines of macrophage activity, interleukin-4 (IL-4), interleukin-5 (IL-5), and IL-10, as well as low levels of IFN- $\gamma .{ }^{81}$ Considering the pattern of cytokine secretion of $\mathrm{T}$ suppressor cells, particularly IL-4, these cell clones have been called T CD8+ cells, Th2 pattern, which contribute to the stimulation of $\mathrm{B}$ lymphocytes, with increased humoral immune res- 
ponse and production of antibodies, making the individual susceptible to disease development. ${ }^{70,71}$

The levels of TNF- $\alpha$ are higher in the serum of tuberculoid patients, suggesting that the destruction of $M$. leprae and the formation of granuloma are associated with the presence of this cytokine. In spite of being involved in defense by means of macrophage activation if produced at high levels and associated with high levels of IFN- $\gamma$, TNF- $\alpha$ contributes to tissue damage and symptoms of erythema nodosum leprosum (ENL). ${ }^{83}$

In the lepromatous form, there is elevated transforming growth factor-beta (TGF- $\beta$ ), which is absent in the tuberculoid form and appears in decreasing levels in borderline leprosy. This cytokine suppresses macrophage activation that inhibits the production of TNF- $\alpha$ and IFN- $\gamma$ which contributes to perpetuate the infection. ${ }^{84,85}$

Furthermore, IL-7 and IL-12 are growth and differentiation factors of $\mathrm{T}$ cells, and they are produced in tuberculoid lesions. ${ }^{86}$ Conversely, IL-13 seems to play a role in the immunosuppression of lepromatous lesions. ${ }^{87}$

In type 1 reaction, there is sudden increase in cellular immune response, with influx of T CD4+ cells and production of IL-1, TNF- $\alpha$, IL-2, and IFN- $\gamma$ in the lesions, Th1 response pattern. ${ }^{8}$ In ENL, there is inflammatory reaction mediated by immune complexes, characterized by increased IL-6, IL-8, and IL-10 in the lesions, suggesting Th2 response, as well as increased TNF- $\alpha$ and TGF- $\beta{ }^{88,89}$

\section{CLASSIFICATION OF CLINICAL FORMS}

Several classifications have been proposed for leprosy over the years as new knowledge about the disease was gained. The Madrid classification, established in the International Leprosy Congress, held in Madrid in 1953, follows the polar system defined in 1936 by Rabello Jr. ${ }^{90,91}$ This system is based on clinical characteristics and the result of skin smears, dividing leprosy into two immunologically unstable groups (indeterminate and borderline) and two stable polar types (tuberculoid and lepromatous).

The classification system of Ridley \& Jopling $(1962,1966)$ uses the concept of spectral leprosy based on clinical, immunological, and histopathological criteria. ${ }^{92,93}$ The tuberculoid (TT) form is at one end of the spectrum and the lepromatous (LL) form is at the other end. The borderline form is divided into borderline-tuberculoid (BT), borderline-lepromatous (BL), according to the greater proximity to one of the poles, and borderline-borderline (BB).

In 1982, the WHO, with operational and therapeutic purposes, established a simplified classification based on the bacterial index (BI). According to this classification, leprosy was divided into paucibacillary $(\mathrm{PB})$ and multibacillary $(\mathrm{MB})$, and $\mathrm{PB}$ patients are those who have a $\mathrm{BI}$ lower than $2+$ and $\mathrm{MB}$ patients are those showing a BI higher than or equal to $2+{ }^{94} \mathrm{In}$ 1988, the WHO recommended the use of a purely clinical classification because there are regions where microscopy examination of skin smear is unavailable, establishing as $\mathrm{PB}$ cases those patients with up to five skin lesions and/or only one nerve trunk involved, whereas $\mathrm{MB}$ cases are those with more than five skin lesions and/or more than one nerve trunk involved..$^{95}$ However, when microscopy examination of skin smear is available, patients with positive results are considered $\mathrm{MB}$, regardless of the number of lesions. Thus, indeterminate, TT and BT patients are included in the PB group. The MB group includes BB, BL, LL and some BT patients.

The combination of the classification by number of lesions with the serological test of lateral flow of $M$. leprae (ML-Flow test), which correlates the BI and the concentration of anti-trisaccharide IgM of PGL-1 in the peripheral blood of patients is an evolution of the operational classification. Seropositive patients are classified as $\mathrm{MB}$ and seronegative patients are considered $\mathrm{PB} .{ }^{96,97}$

\section{CLINICAL MANIFESTATIONS}

\section{Characteristics of clinical forms}

Clinical manifestations depend more on the cellular immune response of the host to $M$. leprae than on the bacillary penetration and multiplication ability. Clinical manifestations are preceded by a long incubation period, between six months and 20 years (mean period of two to four years). Seropositivity to antigens of $M$. leprae has been found nine years before clinical diagnosis..$^{98,99}$ Slow proliferation, low antigenicity and metabolic limitation of $M$. leprae are possible explanations for the long incubation periods of leprosy. ${ }^{100}$ Decreased sensitivity in the lesions, changing sequentially thermal, painful, and tactile sensitivity are typical manifestations.

The indeterminate group is characterized by a small number of hypochromic spots, with slight decrease in sensitivity, without increased nerve thickness (Figure 1).

In the TT form, the disease is limited due to the good cellular immune response of the host to $M$. leprae, with the patients showing single skin lesions or a small number of asymmetric lesions. They are characterized by erythematous plaques, often with elevated external borders and hypochromic center, presenting significant change in sensitivity (Figure 2). The lesions may have alopecia and anhidrosis because of denervation of the skin appendages, and thickening of the nearby nerve sheath, and hyperkeratosis and/or ulceration in the compression areas. Sensitive change in the nerve path, with or without clear thickening, may be the only manifestation, characterizing the primary neural form of the disease. ${ }^{93}$ 


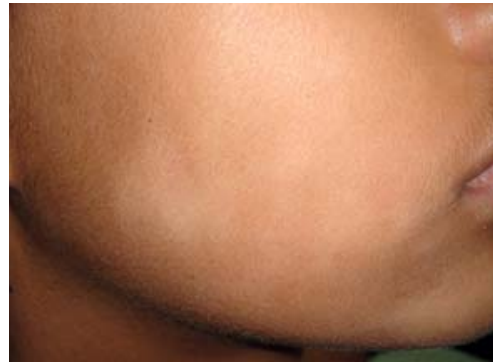

Figure 1:

Indeterminate leprosy: hypochromic spots with indefinite borders on the face

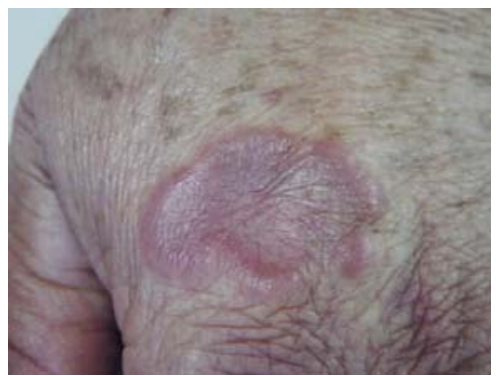

FiguRE 2:

Tuberculoid leprosy: well-defined annular erythematous plaque on the dorsum of the hand

In the LL form, M. leprae multiplies and spreads through the blood because of the absence of cellular immune response to the bacillus. Antibodies are produced, but they do not prevent bacterial proliferation. Skin lesions tend to be multiple and symmetrical, preferably located in the colder areas of the body, characterized by hypochromic, erythematous or bright brownish spots with indefinite borders. These spots may not have loss of sensation. Sometimes, the only noticeable sign is dry skin (Figure 3). Multiple peripheral nerves are compromised, but there is no thickening, unless the patient develops the borderline form of the disease. As the disease progresses, lesions infiltrate forming plaques and nodules (lepromas) ${ }^{93}$ (Figure 4). Edema in the legs and feet and hypoesthesia of the limbs are other common symptoms. In the advanced stages of the disease, the patient's face has a peculiar appearance (leonine facies), characterized by diffuse infiltration and eyelash loss (madarosis) (Figure 5). Mucous membranes, eyes, bones, joints, lymph nodes, blood vessels, upper airways, teeth, and internal organs may be affected. ${ }^{101}$

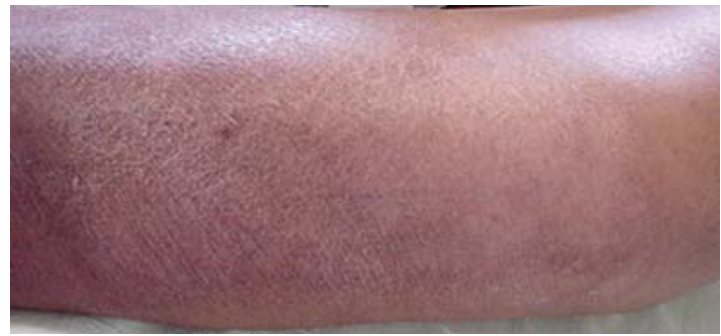

FIGURE 3: Lepromatous leprosy: dry and barely discernible hypochromic spots on the arm

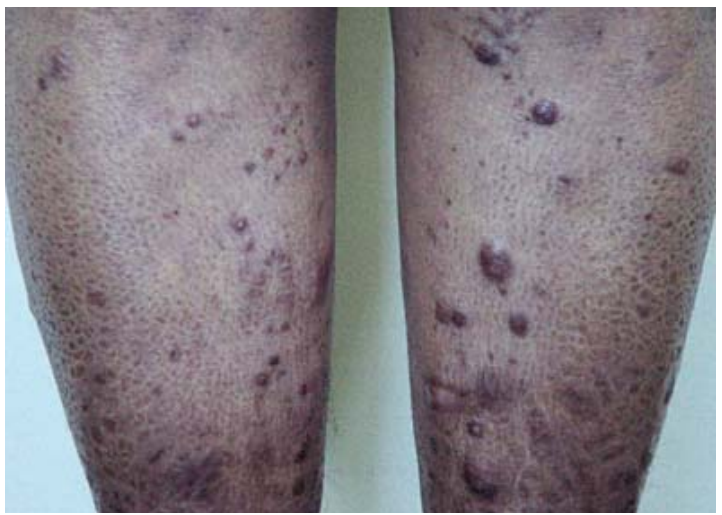

FIGURE 4: Lepromatous leprosy: ichthyosiform appearance of the skin of the legs and lepromas

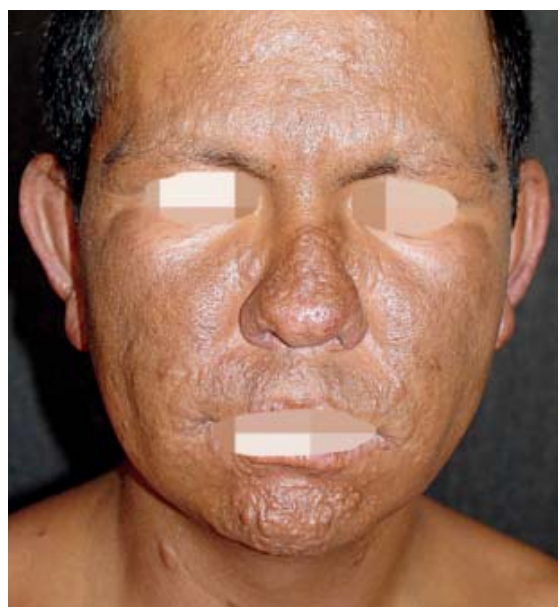

FiguRE 5: Lepromatous leprosy: infiltrated face and madarosis

The borderline group has different clinical manifestations because of varying degrees of cellular immune response to $M$. leprae (Figures 6, 7, and 8). The skin lesions of the BT subgroup resemble the TT form in terms of appearance and loss of sensitivity, but they occur in a larger number and are smaller. Nerve thickening tends to be irregular, less intense, and appears in a larger number. The skin lesions of the BB subgroup exhibit characteristics of the TT and LL forms, with asymmetrical distribution and moderate nerve impairment. The presence of erythematous plaques with fading outer borders, clear inner borders, and hypopigmented oval center (foveal spot) is suggestive of the BB subgroup. The skin lesions of the BL subgroup resemble the LL form, tending to occur in a large number, but not so symmetrical and with loss of sensation in some areas. ${ }^{93}$

\section{Reactional states}

Leprosy reactions result from changes in the immune balance between the host and M. leprae. Such 


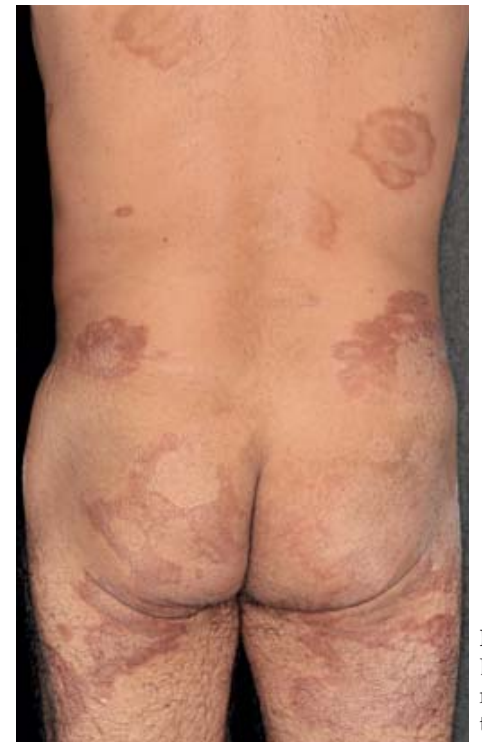

FIGURE 6:

Borderline leprosy: polymorphic appearance of the lesions

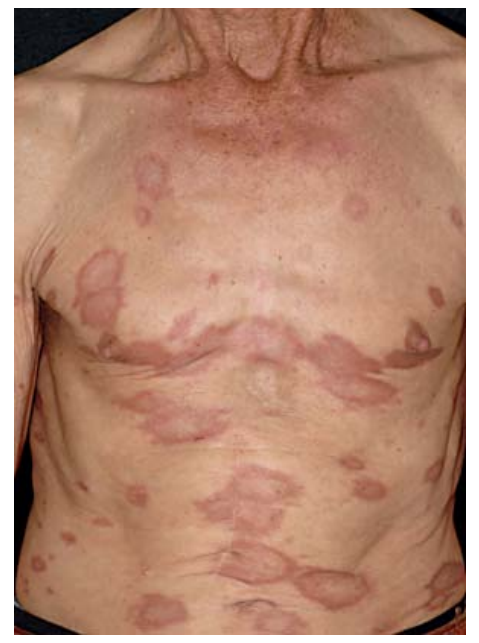

FiguRe 7:

Borderline leprosy: brownish erythematous plaques (foveal spots) in the trunk

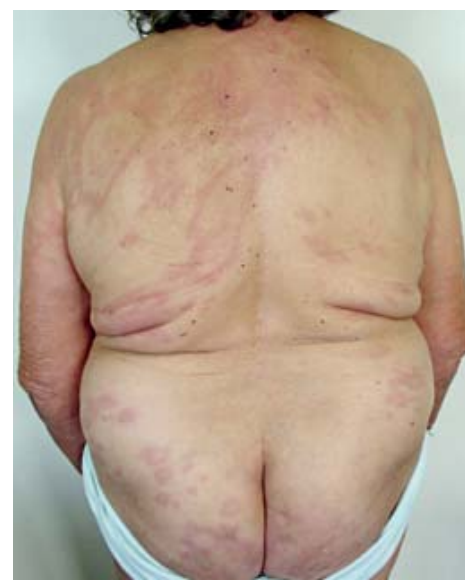

Figure 8:

Borderline leprosy: several erythematous plaques with clear inner borders and indefinite outer borders in the trunk reactions are acute episodes that primarily affect the skin and nerves, being the main cause of morbidity and neurological disability. They may occur during the natural course of the disease, throughout treatment or after it. They are classified into two types: type 1 reaction and type 2 reaction. ${ }^{98,102}$

Type 1 reaction is a result of delayed hypersensitivity and it occurs in borderline patients. These reactions are related to the cellular immune response against mycobacterial antigens and can cause improvement (reversal reaction, pseudo-exacerbation reaction, or ascending reaction) or worsening (degradation reaction or descending reaction) of the disease. Because of the reduction of bacterial load, borderline patients under treatment migrate to the TT pole of the spectrum. Untreated patients show increased bacterial load and the clinical presentation become similar to those of the LL pole because of the deterioration of the cellular immunity. These individuals are classified as subpolar lepromatous. In both cases, the lesions are characterized by hyperesthesia, erythema, and edema, with subsequent scaling and sometimes ulceration (Figure 9). Lesions are usually combined with edema of the extremities and neuritis, with minimal systemic manifestations in reactional individuals close to the TT pole and systemic manifestations in those close to the LL pole. ${ }^{98,102}$

Type 2 reaction or ENL is related to humoral immunity and does not mean immunological improvement. It is believed to represent the body's reaction to substances released by the destroyed bacilli, with deposition of immune complexes in the tissues. It is manifested by sudden worsening, especially during treatment in the LL individuals and, more rarely, in BL patients. Symmetrically distributed subcutaneous inflammatory nodules or target lesions of erythema multiforme occur in any region (Figure 10). There are general symptoms, such as fever, malaise, myalgia, edema, arthralgia, and lymphadenomegaly. Neuritis and internal involvement, such as liver or kidney damage, may also occur. ${ }^{98,102}$ Inflammatory laboratory tests show abnormal results. There may be necrosis because of obliteration of the vascular lumen (necrotic ENL), probably due to vasculitis with leukocytoclasia due to deposition of immune complexes within vessel walls, with formation of thrombi and ischemia. This should not be confused with Lucio's phenomenon, which occurs in Lucio's leprosy and classic lepromatous leprosy, where a large amount of bacilli infect the capillary endothelium leading to endothelial proliferation, thrombosis, and vascular occlusion. ${ }^{103}$

\section{Neurological changes}

In addition to the involvement of dermal free nerve endings, which leads to changes in the sensitivi- 


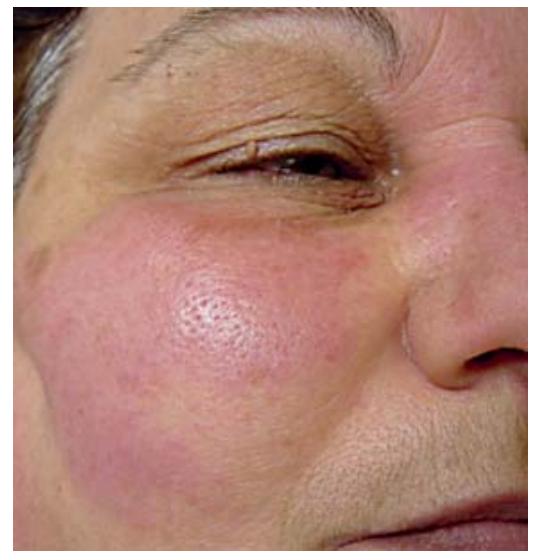

Figure 9:

Type 1 reaction: erythematosus plaque on the face

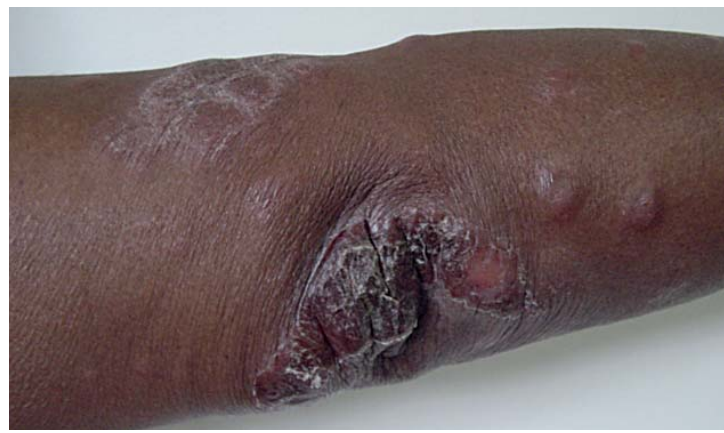

FIGURE 10: Erythema nodosum leprosum: inflammatory nodules in the upper limb

ty of skin lesions, M. leprae may invade peripheral nerve trunks and cause neuritis. Such lesions develop slowly, with variable pain symptoms, and may cause functional changes. There are exacerbations during the reactions, but they may be silent; in which case, there are functional changes with no pain. ${ }^{104}$

Peripheral neuropathy of leprosy is mixed (sensory, motor, and autonomic), and its pattern is that of mononeuropathy or multiple mononeuropathy. Nerves may become thickened, irregular, and painful on palpation. Hypoesthesia or anesthesia, paresis or paralysis, decreased muscle strength, amyotrophy, tendon retraction, joint stiffness, vasomotor dysfunction, decreased sebaceous and sweat gland secretions may occur with disease progression. These neurological damage contribute to the frequent occurrence of lesions, especially on the hands, feet, and eyes, with occurrence of skin dryness, fissures, and ulcerations, secondary infection in the bone and soft tissues, and bone resorption, causing deformities. ${ }^{104-107}$ Neuritis often cause sequelae and may lead to chronic pain along the affected nerves, which is called neuropathic pain. ${ }^{8}$

The most commonly affected nerves are: the facial $\left(7^{\text {th }}\right.$ cranial $)$ and trigeminal $\left(5^{\text {th }}\right.$ cranial) nerves in the face; the ulnar, median, and radial nerves in the upper limbs; and the common fibular and posterior tibial nerves in the lower limbs. ${ }^{8}$

\section{Facial nerve lesion:}

Facial nerve lesion leads mainly to decreased muscle strength of the eyes and nasal and ocular dryness. The lesion of the zygomatic branch produces orbicularis paralysis and lagophthalmos with or without ectropion. The lesion of the ophthalmic branch of the trigeminal nerve mainly causes decreased sensitivity of the nose and cornea. These changes predispose to keratitis, ulcer, infection, and blindness. The destruction of the fibers of the autonomic nervous system in the nose cause atrophic rhinitis with reduced nasal mucus and decreased blood supply; thus the mucosa becomes pale and fragile with thinned cartilage, which sometimes collapse. ${ }^{107-110}$

\section{Nerve lesion of the upper limbs:}

Ulnar nerve lesion causes hypoesthesia or anesthesia, as well as sweating and circulation disorders of the inner edge of the hand and the 4th and 5th fingers, with paralysis and hypotrophy of most intrinsic muscles of the hand, resulting in claw deformity, characterized by hyperextension of the metacarpophalangeal joints and flexion of the interphalangeal joints, especially of the $4^{\text {th }}$ and $5^{\text {th }}$ fingers. This lesion may cause hypothenar and thenar atrophy, as well as atrophy of the interosseous spaces. The little finger becomes abducted and thumb adduction is impaired. Median nerve lesion causes paralysis and atrophy of some muscles of the thenar eminence and loss of palmar sensitivity in the thumb, index, and middle fingers, as well as in the radial and volar half of the ring finger. When muscles are affected at the wrist, there is loss of thumb opponency and hyperextension of the metacarpophalangeal joints of the $2^{\text {nd }}$ and $3^{\text {rd }}$ fingers (claw). When the lesion occurs at a more proximal level, the extrinsic muscles are also compromised, with loss of control of the distal phalanx flexion of the index and middle fingers, loss of function of superficial flexors, pronation impairment, and tendency to ulnar deviation of the wrist. These symptoms make it difficult to handle small objects and to grasp larger objects. Radial nerve lesion is rare, occurring only after the involvement of the ulnar and median nerves (triple paralysis); it is detected by the flexion position (dropwrist) due to the paralysis of the extensor muscles of the wrist, fingers and thumb, making it difficult to grasp objects due to inability to position the hand to hold them, in addition to the atrophy of the dorsal region of the forearm. Sensitivity is impaired in the dorsal aspect of the thumb to the third finger and in the radial portion of the fourth finger. ${ }^{107,108,111}$ 
Nerve lesion of the lower limbs:

The common fibular nerve may be injured in its superficial and deep branches. Deep fibular nerve lesion leads to changes in the sensitivity of the region above the first metatarsal space, as well as paralysis of ankle and toes dorsiflexion. Superficial fibular nerve lesion leads to loss of sensitivity across the lateral and dorsal surface of the leg and change in the movements of eversion of the foot (remaining in plantar flexion), side of the leg, and dorsum of the foot. When both branches are affected, there is foot drop and atrophy of the lateral and anterior parts of the leg. Posterior tibial nerve lesion causes plantar anesthesia and paralysis of the intrinsic muscles of the foot, with hyperextension of the metatarsophalangeal joints and flexion of the proximal and distal interphalangeal joints (claw toes), in addition to atrophy of the plantar muscles. ${ }^{107,108}$

\section{Systemic changes}

Leprosy may affect multiple organ systems, most often in MB patients, particularly in lepromatous, often causing no symptoms. Such involvement may be caused by bacteremia with $M$. leprae, but, most often, the reactional states are responsible for this health impairment. Secondary amyloidosis in several organs is another common cause of kidney damage, and it is associated with the prolonged course of leprosy with recurrent reactional states. Concomitant diseases, side effects of drug treatment, etc, are other possible contributing factors. ${ }^{101,112}$

Respiratory system: M. leprae affects the upper airways (nose, pharynx, larynx, epiglottis, trachea), especially in type 2 reactions. Involvement of the oral mucosa is not frequent. ${ }^{11-115}$ Bronchi are occasionally affected and lungs are usually spared. The association of leprosy and pulmonary tuberculosis is often reported. ${ }^{112}$

Cardiovascular system: arrhythmias, dyspnea, signs of stasis, ventricular hypertrophy and ST-segment changes are reported more frequently in $\mathrm{MB}$ patients than in PB patients. Autonomic dysfunctions are caused by the infiltration of the sympathetic and parasympathetic cardiac nerves. Coronary disease and arteriographic abnormalities of peripheral vessels are reported at a frequency of $11 \%$ and $50 \%$ of patients, respectively. Infected endothelial cells contribute to the formation of ischemic ulcers. ${ }^{112}$

Kidneys and urinary pathways: the involvement of the kidneys is usually due to type 2 reaction or secondary amyloidosis, because $M$. leprae rarely affects the renal parenchyma. There may be glomerulonephritis, interstitial nephritis, nephrotic syndrome, pyelonephritis, acute tubular necrosis, leading to renal failure and death. Ureters, bladder, and urethra are usually spared. ${ }^{112}$
Endocrine system: there is significant endocrine involvement, especially in male patients, who have an incidence of up to $90 \%$ of testicular involvement, resulting from orchitis, which, with the involvement of the epididymis, can lead to infertility, sexual impotence, and gynecomastia, among other symptoms. Adrenal lesions are reported in about one third of the patients, mainly in the cortex. Inadequate response to stress due to frequent use of corticosteroids in the reactions is a possible event. Thyroid, parathyroid, pituitary and pineal glands are rarely affected. ${ }^{112,116}$ The involvement of the liver by $M$. leprae can occur in all clinical forms of the disease, but is more common in the lepromatous form. It usually is asymptomatic, showing normal liver function tests. When there are abnormal results, other possible causes of dysfunction should be investigated, especially reactions. Secondary hepatic amyloidosis is associates with hepatomegaly. ${ }^{112}$

Hematologic and lymphatic system: bacillemia is present in $90 \%$ of lepromatous patients. Bacilli-laden reticuloendothelial cells are frequent in the liver, spleen, and bone marrow. Bone marrow infiltration can cause pancytopenia. There may be surface lymphadenopathy in all skin draining ganglion chains. The iliac, femoral, and paraaortic lymph nodes, as well as those belonging to the portal system, are among the deep and internal lymph nodes affected. ${ }^{112}$

The gastrointestinal tract and female reproductive system are almost always spared. There are reports of low birth weight newborns; pregnancy and lactation predispose to reactions worsening, and recurrence of the disease. The central nervous system is also spared; however, as previously mentioned, involvement of the peripheral nervous system is a classic manifestation. ${ }^{112}$

\section{DIFFERENTIAL DIAGNOSIS}

The list of differential diagnosis of leprosy is extremely complex because of the variety of clinical manifestations. The indeterminate form must be differentiated from hypochromic lesions or even achromic lesions, such as pityriasis alba, pityriasis versicolor, hypochromic nevus, postinflammatory hypopigmentation, and vitiligo. Tuberculoid and borderline lesions may be confused with granuloma annulare, figurative erythema, infectious sarcoid lesions or sarcoidosis, pityriasis rosea, psoriasis, lupus erythematosus, drug eruptions, among others. The lepromatous form may resemble scleroderma, mycosis fungoides, pellagra, asteatosis, ichthyosis, and eczema; multibacillary lesions must be distinguished from secondary and tertiary syphilis, diffuse leishmaniasis, neurofibromatosis, xanthomas, lymphomas, and other tumors. In those case that start with ENL or erythema multiforme, other etiologies should be investigated. 
The primary neural forms resemble the diseases that cause mononeuropathy or multiple mononeuropathy, including inflammatory, metabolic, infectious, congenital or hereditary diseases, tumors, and traumas. When there are specific systemic manifestations in multibacillary leprosy, it is important to rule out any diseases that may also cause such manifestations, including systemic lupus erythematosus, rheumatoid arthritis, dermatopolymyositis, and systemic vasculitis. The differential diagnosis of lesions of the nerve trunks of the limbs must be established based on lesions caused by trauma, infection, bleeding, degeneration, and tumors in these nerve trunks that can also cause amyotrophy and paralysis.

\section{REFERENCES}

1. Eidt LM. Breve história da hanseníase: sua expansão do mundo para as Américas, o Brasil e o Rio Grande do Sul e sua trajetória na saúde pública brasileira. Saúde Soc. 2004;13:76-88

2. Cavaliere IAL, Costa SG. Isolamento social, sociabilidades e redes sociais de cuidados. Physis. 2011;21:491-516.

3. Cunha VS. solated 'like us' or isolated 'among us'?: the controversy within the National Academy of Medicine over compulsory isolation of leprosy sufferers. Hist Cienc Saude Manguinhos. 2010;17:939-954.

4. Opromolla PA, Martelli ACC. Terminology related to Hansen's disease. An Bras Dermatol. 2005;80:293-4.

5. Global leprosy situation, 2012. Wkly Epidemiol Rec. 2012;87:317-28.

6. Paho.org [homepage on the internet]. World Health Organization. Elimination of leprosy as a public health problem. Leprosy Resolution WHA 44.9, 44th World Health Assembly. Geneva; 1991. [cited 2012 oct 19]. Availabre from: http://www.paho.org/English/AD/DPC/CD/lep-wha-1991.htm.

7. Saude.gov.br [homepage on the Internet]. Distribuição da hanseníase no Brasil. [acesso 19 out 2012]. Disponível em: http://portal.saude.gov.br/portal/saude/profissional/visualizar texto.cfm?idtxt=31200.

8. Brasil. Ministério da Saúde. Portaria $n^{0} 3.125$, de 07 de outubro de 2010. Aprova as Diretrizes para Vigilância, Atenção e Controle da hanseníase. [acesso 19 out 2012]. Disponível em: http://portal.saude.gov.br/portal/arquivos/pdf/portaria n 3125 hanseniase_2010.pdf

9. Talhari S, Grossi MA, Oliveira ML, Gontijo B, Talhari C, Penna GO. Hansen's disease: a vanishing disease? Mem Inst Oswaldo Cruz. 2012;107:13-6.

10. Penna MLF, Oliveira MLW, Carmo EH, Penna GO, Temporão JG. The influence of increased access to basic healthcare on the trends in Hansen's disease detection rate in Brazil from 1980 to 2006. Rev Soc Bras Med Trop. 2008;41:6-10.

11. Barbieri CL, Marques HH. Leprosy in children and adolescents: bibliographical review and current situation in Brazil. Pediatria (São Paulo). 2009;31:281-90.

12. Ignotti $\mathrm{E}$, Rodrigues AM, Andrade VLG, Valente JG. Aplicação de métodos de estimativa da prevalência de hanseníase no Estado de Mato Grosso. Rev Bras Epidemiol. 2004;7:155-66.

13. Goulart IB, Dias CM, Oliveira ACS, Silva AA, Alves RR, Quaresmin CR et al. Grau de incapacidade: indicador de prevalência oculta e qualidade do programa de controle da hanseníase em um centro de saúde-escola no município de Uberlândia MG. Hansen int. 2002;27:5-13.

14. da Cunha MD, Cavaliere FA, Hércules FM, Duraes SM, de Oliveira ML, de Matos HJ. Os indicadores da hanseníase e as estratégias de eliminação da doença, em município endêmico do Estado do Rio de Janeiro, Brasil. Cad Saude Publica. 2007;23:1187-97.

15. Rees RJW, Young DB. The microbiology of leprosy. In: Hastings RC, editor. Leprosy. 2nd ed. New York: Churchill Livingstone; 1994. p.49-83.

16. Nolte FS, Metchok B. Mycobacterium. In: Murray PR, Baron EJ, Pfaller MA, Tenover FC, Yolken RH, editors. Manual of clinical microbiology. 6th ed. Washington: American Society for Microbiology; 1995. p. 400-37.

17. Shepard CC. Temperature optimum of Mycobacterium leprae in mice. J Bacteriol. 1965;90:1271-5

18. Hastings RC, Brand PW, Mansfield RE, Ebner JD. Bacterial density in the skin in lepromatous leprosy as related to temperature. Lepr Rev. 1968;39(2):71-4.

19. Desikan KV. Viability of Mycobacterium leprae outside the human body. Lepr Rev. 1977;48:231-5.

20. Draper P. The bacteriology of Mycobacterium leprae. Tubercle. 1983;64:43-56.

21. Hirata T. Electron microscopic observations of cell wall and cytoplasmic membrane in murine and human leprosy bacilli. Int J Lepr Other Mycobact Dis. 1985;53:433-40.

22. Cole ST, Eiglmeier K, Parkhill J, James KD, Thomson NR, Wheeler PR, et al. Massive gene decay in the leprosy bacillus. Nature. 2001;409:1007-11.
23. Vissa VD, Brennan PJ. The genome of Mycobacterium leprae: a minimal mycobacterial gene set. Genome Biol. 2001;2:REVIEWS1023.

24. Deps PD, Antunes JM, Tomimori-Yamashita J. Detection of Mycobacterium leprae infection in wild nine-banded armadillos (Dasypus novemcinctus) using the rapid ML Flow test. Rev Soc Bras Med Trop. 2007;40:86-7.

25. Donham KJ, Leininger JR. Spontaneous leprosy-like disease in a chimpanzee. J Infect Dis. 1977;136:132-6.

26. Walsh GP, Meyers WM, Binford CH, Gerone PJ, Wolf RH, Leininger JR. Leprosy-a zoonosis. Lepr Rev. 1981;52:77-83.

27. Kazda J, Ganapati R, Revankar C, Buchanan TM, Young DB, Irgens LM.. Isolation of environment-derived Mycobacterium leprae from soil in Bombay. Lepr Rev. 1986;57:201-8.

28. Matsuoka M, Izumi S, Budiawan T, Nakata N, Saeki K. Mycobacterium leprae DNA in daily using water as a possible source of leprosy infection. Indian J Lepr. 1999;71:61-7.

29. Bona SH, Fonseca APM, Silva ACL, Costa RJ. Bacilos álcool-ácido resistentes no Culex fatigans. An Bras Dermatol. 1985;60:163-70.

30. Shepard CC. The nasal excretion of Mycobacterium leprae in leprosy. Int J Lepr. 1962;30:10-8.

31. Martins AC, Miranda A, Oliveira ML, Bührer-Sékula S, Martinez A. Estudo da mucosa nasal de contatos de hanseníase, com positividade para o antígeno glicolipídio fenólico 1. Braz J Otorhinolaryngol. 2010;76:579-87.

32. Job CK. Nasal mucosa and abraded skin are the two routes of entry of Mycobacterium leprae. Star. 1990;49:1.

33. Ghorpade A. Inoculation (tattoo) leprosy: a report of 31 cases. J Eur Acad Dermatol Venereol. 2002;16:494-9.

34. Santos AR, Balassiano V, Oliveira ML, Pereira MA, Santos PB, Degrave WM, et al. Detection of Mycobacterium leprae DNA by polymerase chain reaction in the blood of individuals, eight years after completion of anti-leprosy therapy. Mem Inst Oswaldo Cruz. 2001;96:1129-33.

35. Melsom R, Harboe M, Duncan ME, Bergsvik H. IgA and IgM antibodies against Mycobacterium leprae in cord sera and in patients with leprosy: an indicator of intrauterine infection in leprosy. Scand J Immunol. 1981;14:343-52.

36. Pedley JC. The presence of M. leprae in human milk. Lepr Rev. 1967;38:239-42.

37. Klatser PR, van Beers S, Madjid B, Day R, de Wit MY. Detection of Mycobacterium leprae nasal carriers in populations for which leprosy is endemic. J Clin Microbiol. 1993;31:2947-51.

38. Hatta M, van Beers SM, Madjid B, Djumadi A, de Wit MY, Klatser PR. Distribution and persistence of Mycobacterium leprae nasal carriage among a population in which leprosy is endemic in Indonesia. Trans R Soc Trop Med Hyg. 1995;89:3815.

39. van Beers SM, de Wit MY, Klatser PR. The epidemiology of Mycobacterium leprae: recent insight. FEMS Microbiol Lett. 1996;136:221-30.

40. Cree IA, Smith WC. Leprosy transmission and mucosal immunity: towards eradication? Lepr Rev. 1998;69:112-21.

41. Pattyn SR, Ursi D, leven M, Grillone S, Raes V. Detection of Mycobacterium leprae by the polymerase chain reaction in nasal swabs of leprosy patients and their contacts. Int J Lepr Other Mycobact Dis. 1993;61:389-93.

42. van Beers SM, Izumi S, Madjid B, Maeda Y, Day R, Klatser PR. An epidemiological study of leprosy infection by serology and polymerase chain reaction. Int J Lepr Other Mycobact Dis. 1994;62:1-9.

43. Ramaprasad P, Fernando A, Madhale S, Rao JR, Edward VK, Samson PD, et al. Transmission and protection in leprosy: indications of the role of mucosal immunity. Lepr Rev. 1997;68:301-15.

44. Izumi S, Budiawan T, Saeki K, Matsuoka M, Kawatsu K. An epidemiological study on Mycobacterium leprae infection and prevalence of leprosy in endemic villages by molecular biological technique. Indian J Lepr. 1999;71:37-43. 
45. Patrocínio LG, Goulart IM, Goulart LR, Patrocínio JA, Ferreira FR, Fleury RN. Detection of Mycobacterium leprae in nasal mucosa biopsies by the polymerase chain reaction. FEMS Immunol Med Microbiol. 2005;44:311-6.

46. Job CK, Jayakumar J, Kearney M, Gillis TP. Transmission of leprosy: a study of skin and nasal secretions of household contacts of leprosy patients using PCR. Am J Trop Med Hyg. 2008;78:518-21.

47. Baumgart KW, Britton WJ, Mullins RJ, Basten A, Barnetson RS. Subclinical infection with Mycobacterium leprae--a problem for leprosy control strategies. Trans $\mathrm{R}$ Soc Trop Med Hyg. 1993;87:412-5

48. Brasil MTLRF, Oliveira LR, Melo CS, Nakamura PM, Rimoli NS, Cavalari FS et al. Aplicação do teste Elisa anti-PGL-1 em localidade com alta edemicidade de hanseníase, na Região Norte do Estado de São Paulo. Hansen Int. 1998;23:35-48.

49. de Wit MY, Douglas JT, McFadden J, Klatser PR. Polymerase chain reaction for detection of Mycobacterium leprae in nasal swab specimens. J Clin Microbiol. 1993;31:502-6

50. Fine PE, Sterne JA, Pönnighaus JM, Bliss L, Saui J, Chihana A, et al. Household and dwelling contact as risk factors for leprosy in northern Malawi. Am J Epidemiol. 1997:146:91-102.

51. Moet FJ, Meima A, Oskam L, Richardus JH. Risk factors for the development of clinical leprosy among contacts, and their relevance for targeted interventions. Lepr Rev. 2004;75:310-26.

52. Mira MT, Sindeaux RHM, Ramos GB, Sotomaior VS, Medeiros Fava V. Aspectos genéticos da suscetibilidade do hospedeiro à hanseníase. Salud cienc. 2011:18:138-41

53. Prevedello FC, Mira MT. Leprosy: a genetic disease? An Bras Dermatol. 2007;82:451-9

54. Mira MT, Alcaïs A, Nguyen VT, Moraes MO, Di Flumeri C, Vu HT, et al. Susceptibility to leprosy is associated with PARK2 and PACRG. Nature. 2004;427:636-40.

55. Alcaïs A, Alter A, Antoni G, Orlova M, Nguyen VT, Singh M, et al. Stepwise replication identifies a low-producing lymphotoxin-alpha allele as a major risk factor for early-onset leprosy. Nat Genet. 2007:39:517-22

56. Cooke GS, Hill AV. Genetics of susceptibility to human infectious disease. Nat Rev Genet. 2001:2:967-77.

57. Roy S, McGuire W, Mascie-Taylor CG, Saha B, Hazra SK, Hill AV, et al. Tumor necrosis factor promoter polymorphism and susceptibility to lepromatous leprosy. J Infect Dis. 1997;176:530-2.

58. Moraes MO, Pacheco AG, Schonkeren JJ, Vanderborght PR, Nery JA, Santos AR, et al. Interleukin-10 promoter single-nucleotide polymorphisms as markers for disease susceptibility and disease severity in leprosy. Genes Immun. 2004;5:5925 .

59. Malhotra D, Darvishi K, Sood S, Sharma S, Grover C, Relhan V, et al. IL-10 promoter single nucleotide polymorphisms are significantly associated with resistance to leprosy. Hum Genet. 2005;118:295-300.

60. Santos AR, Suffys PN, Vanderborght PR, Moraes MO, Vieira LM, Cabello PH, et al. Role of tumor necrosis factor-alpha and interleukin-10 promoter gene polymorphisms in leprosy. J Infect Dis. 2002;186:1687-91

61. Shaw MA, Donaldson IJ, Collins A, Peacock CS, Lins-Lainson Z, Shaw JJ, et al. Association and linkage of leprosy phenotypes with HLA class II and tumour necrosis factor genes. Genes Immun. 2001;2:196-204.

62. Franceschi DS, Mazini PS, Rudnick CC, Sell AM, Tsuneto LT, Ribas ML, et al. Influence of TNF and IL10 gene polymorphisms in the immunopathogenesis of leprosy in the south of Brazil. Int J Infect Dis. 2009;13:493-8.

63. Sarno EN, Santos AR, Jardim MR, Suffys PN, Almeida AS, Nery JA, et al. Pathogenesis of nerve damage in leprosy: genetic polymorphism regulates the production of TNF? Lepr Rev. 2000;71:S154-8

64. Zhang FR, Huang W, Chen SM, Sun LD, Liu H, Li Y, et al. Genomewide association study of leprosy. N Engl J Med. 2009:361:2609-18.

65. Meisner SJ, Mucklow S, Warner G, Sow SO, Lienhardt C, Hill AV. Association of NRAMP1 polymorphism with leprosy type but not susceptibility to leprosy in west Africans. Am J Trop Med Hyg. 2001:65:733-5.

66. Siddiqui MR, Meisner S, Tosh K, Balakrishnan K, Ghei S, Fisher SE, et al. A major susceptibility locus for leprosy in India maps to chromosome 10p13. Nat Genet. 2001;27:439-41.

67. Roy S, Frodsham A, Saha B, Hazra SK, Mascie-Taylor CG, Hill AV. Association of vitamin D receptor genotype with leprosy type. J Infect Dis. 1999;179:187-91.

68. Bochud PY, Hawn TR, Siddiqui MR, Saunderson P, Britton S, Abraham I, et al. Tolllike receptor 2 (TLR2) polymorphisms are associated with reversal reaction in leprosy. J Infect Dis. 2008;197:253-61

69. Scollard DM, Adams LB, Gillis TP, Krahenbuhl JL, Truman RW, Williams DL. The continuing challenges of leprosy. Clin Microbiol Rev. 2006;19:338-81.

70. Modlin RL, Bloom BR. Immune regulation: learning from leprosy. Hosp Pract (Off Ed). 1993;28:71-4, 77-80, 83-4.

71. Mendonça VA, Costa RD, Melo GEBA, Antunes CM, Teixeira AL. Immunology of leprosy. An Bras Dermatol. 2008;83:343-50.
72. Oliveira MLW, Cavaliére FAM, Maceira JMP, Bührer-Sékula S. The use of serology as an additional tool to support diagnosis of difficult multibacillary leprosy cases: lessons from clinical care. Rev Soc Bras Med Trop. 2008:41:27-33.

73. Ottenhoff TH. Immunology of leprosy: lessons from and for leprosy. Int J Lepr Other Mycobact Dis. 1994:62:108-21.

74. Van Voorhis WC, Kaplan G, Sarno EN, Horwitz MA, Steinman RM, Levis WR, et al. The cutaneous infiltrates of leprosy: cellular characteristics and the predominant Tcell phenotypes. N Engl J Med. 1982;307:1593-7.

75. Modlin RL, Hofman FM, Taylor CR, Rea TH. T lymphocyte subsets in the skin lesions of patients with leprosy. J Am Acad Dermatol. 1983;8:182-9.

76. Narayanan RB, Bhutani LK, Sharma AK, Nath I. T cell subsets in leprosy lesions: in situ characterization using monoclonal antibodies. Clin Exp Immunol. 1983:51:421-9.

77. Modlin RL, Mehra V, Wong L, Fujimiya Y, Chang WC, Horwitz DA, et al. Suppressor T lymphocytes from lepromatous leprosy skin lesions. J Immunol. 1986;137:2831-4.

78. Modlin RL, Melancon-Kaplan J, Young SM, Pirmez C, Kino H, Convit J, et al. Learning from lesions: patterns of tissue inflammation in leprosy. Proc Natl Acad Sci U S A. 1988;85:1213-7.

79. Sieling PA, Abrams JS, Yamamura M, Salgame P, Bloom BR, Rea TH, et al, Immunosuppressive roles for IL-10 and IL-4 in human infection: In vitro modulation of T cell responses in leprosy. J Immunol. 1993;150:5501-10.

80. Scollard DM. Inside the skin: the local immune and inflammatory milieu in leprosy. Am J Trop Med Hyg. 1991;44:17-23.

81. Yamamura M, Uyemura K, Deans RJ, Weinberg K, Rea TH, Bloom BR, BR et al. Defining protective responses to pathogens: cytokine profiles in leprosy lesions. Science. 1991;254:277-9.

82. Sieling PA, Modlin RL. T cell and cytokine patterns in leprosy skin lesions. Springer Semin Immunopathol. 1992:13:413-26.

83. Silva CL, Foss NT. Tumor necrosis factor in leprosy patients. J Infect Dis 1989:159:787-90.

84. Warwick-Davies J, Lowrie DB, Cole PJ. Selective deactivation of human monocyte functions by TGF-beta. J Immunol. 1995;155:3186-93.

85. Henao Ml, Montes C, París SC, García LF. Cytokine gene polymorphisms in Colombian patients with different clinical presentations of tuberculosis. Tuberculosis (Edinb). 2006;86:11-9.

86. Hsieh CS, Macatonia SE, Tripp CS, Wolf SF, O'Garra A, Murphy KM. Development of Th1 CD4+ T-cells through IL-12 produced by Listeria-induced macrophages. Science. 1993;260:547-9

87. Sieling PA, Modlin RL. Cytokine patterns at the site of mycobacterial infection. Immunobiology. 1994;191:378-87.

88. Yamamura M, Wang XH, Ohmen JD, Uyemura K, Rea TH, Bloom BR, et al. Cytokine patterns of immunologically mediated tissue damage. J Immunol. 1992;149:14705.

89. Foss NT. Aspectos imunológicos da hanseníase. Medicina (Ribeirão Preto) 1997:30:335-9.

90. Report of the committee on classification. International Congress of leprosy, Madrid; 1953. Int J Lepr. 1953;21:504-16.

91. Rabello Júnior FE. Uma classificação clínico-epidemiológica das formas de lepra. Rev Bras Leprol. 1936;:375-410.

92. Ridley DS, Jopling WH. A classification of leprosy for research purposes. Lepr Rev. 1962;33:119-28

93. Ridley DS, Jopling WH. Classification of leprosy according to immunity. A fivegroup system. Int J Lepr Other Mycobact Dis. 1966;34:255-73.

94. Chemotherapy of leprosy for control programmes. World Health Organ Tech Rep Ser. 1982;675:1-33.

95. WHO Expert Committee on Leprosy. World Health Organ Tech Rep Ser 1988;768:1-51.

96. Contin LA, Alves CJM, Fogagnolo L, Nassif PW, Barreto JA, Lauris JRP L et al. Use of the ML-Flow test as a tool in classifying and treating leprosy. An Bras Dermatol. 2011;86:91-5

97. Bührer-Sékula S, Smits HL, Gussenhoven GC, van Leeuwen J, Amador S, Fujiwara $\mathrm{T}$, et al. Simple and fast lateral flow test for classification of leprosy patients and identification of contacts with high risk of developing leprosy. J Clin Microbiol. 2003:41:1991-5

98. Nery JAC, Sales AM, Illarramendi X, Duppre NC, Jardim MR, Machado AM Contribuição ao diagnóstico e manejo dos estados reacionais: Uma abordagem prática. An bras dermatol. 2006;81(4):367-375.

99. Douglas JT, Cellona RV, Fajardo TT Jr, Abalos RM, Balagon MV, Klatser PR Prospective study of serological conversion as a risk factor for development of leprosy among household contacts. Clin Diagn Lab Immunol. 2004;11:897-900.

100. Noordeen SK. Long term effects of chemoprophylaxis among contacts of lepromatous cases. Results of 8 1/2 years follow-up. Lepr India. 1977:49:504-9. 
101. Meneses S, Cirelli NM, Aranzazu N, Rondon Lugo AJ. Lepra visceral: presentacion de dos casos y revision de la literatura. Dermatol Venez. 1988;26:79-84.

102. Kahawita IP, Walker SL, Lockwood DNJ. Leprosy type 1 reactions and erythema nodosum leprosum. An Bras Dermatol. 2008;83:75-82.

103. Monteiro R, Abreu MA, Tiezzi MG, Roncada EV, Oliveira CC, Ortigosa LC. Lucio's phenomenon: another case reported in Brazil. An Bras Dermatol. 2012;87:296300.

104. Garbino JA. 0 paciente com suspeita de hanseníase primariamente neural / The patient with suspicion of primarily neural leprosy. Hansen Int. 2007;32:203-6.

105. Martins CF. Exame palpatório de nervos periféricos (espessados na hanseníase) e suas vias anatômicas. An Bras Dermatol. 1995;70:247-50.

106. Agrawal A, Pandit L, Dalal M, Shetty JP. Neurological manifestations of Hansen's disease and their management. Clin Neurol Neurosurg. 2005;107:445-54

107. Ministério da Saúde. Secretaria de Vigilância em Saúde. Departamento de Vigilância Epidemiológica. Caderno de prevenção e reabilitação em hanseníase. 3. ed., rev. e ampl Brasília : Ministério da Saúde; 2008. 140 p. (Série A. Normas e Manuais Técnicos) (Cadernos de prevenção e reabilitação em hanseníase; n. 1).

108. Lehman LF, Orsini MBP, Fuzikawa PL, Lima RC, Gonçalves SD. Avaliação neurológica simplificada. Belo Horizonte: ALM internacional, 1997. 104 p.

109. Gopinath DV, Thappa DM, Jaishankar TJ. A clinical study of the involvement of cranial nerves in leprosy. Indian J Lepr. 2004;76:1-9.

110. Lewallen S, Tungpakorn NC, Kim SH, Courtright P. Progression of eye disease in "cured" leprosy patients: implications for understanding the pathophysiology of ocular disease and for addressing eyecare needs. Br J Ophthalmol. 2000;84:81721.

111. Mattar Jr R, Azze RJ. Lesão dos nervos periféricos. In: Mattar Júnior R, Azzer RJ. Atualização em traumatologia do aparelho locomotor. [acesso 19 out 2012]. Disponível em: http://www.ronaldoazze.com.br/fasciculo/fasciculo3.PDF

112. Klioze AM, Ramos-Caro FA. Visceral leprosy. Int J Dermatol. 2000;39:641-58.

113. de Abreu MA, Michalany NS, Weckx LL, Neto Pimentel DR, Hirata CH, de Avelar Alchorne MM. The oral mucosa in leprosy: a clinical and histopathological study. Braz J Otorhinolaryngol. 2006;72:312-6.

114. Morgado de Abreu MA, Neto Pimentel DR, Morgado de Abreu NM, Watashi Hirata $\mathrm{CH}$, Michalany NS, Maurice Weckx LL, et al. Presence of oral lesions in leprosy patients does not imply involvement by Mycobacterium leprae. Oral Surg Oral Med Oral Pathol Oral Radiol Endod. 2010;109:328-9.

115. de Abreu MA, Alchorne MM, Michalany NS, Weckx LL, Pimentel DR, Hirata CH. The oral mucosa in paucibacillary leprosy: a clinical and histopathological study. Oral Surg Oral Med Oral Pathol Oral Radiol Endod. 2007;103:e48-52.

116. Leal AMO. Endocrine changes in leprosy. Medicina (Ribeirão Preto). 1997; 340-4.
MAILING ADDRESS:

Marilda Aparecida Milanez Morgado de Abreu

Hospital Regional de Presidente Prudente

Rua José Bongiovani, 1297

Cidade Universitária

19050-680 - Presidente Prudente - SP

Brazil

E-mail:marildaderma@bol.com.br

How to cite this article: Lastória JC, Morgado de Abreu MAM. Leprosy (part 1): review of the epidemiological, clinical and etiopathogenic aspects. An Bras Dermatol. 2014;89(2):205-18. 


\section{QUESTIONS}

1. Considering the epidemiological aspects of leprosy, choose the wrong statement:

a) Southeast Asia, Americas, Africa, Eastern Pacific and Western Mediterranean still concentrate a large number of cases of leprosy.

b) The prevalence rate of leprosy should be lower than 1 case per 100,000 inhabitants so that it could be consider a resolved public health problem.

c) The prevalence rate of leprosy in Brazil in 2011 was 1.54 cases per 10,000 inhabitants.

d) In Brazil, leprosy is unevenly distributed, and the Midwest region has the highest prevalence rate.

2. Consider the following statements about leprosy and choose the wrong statement:

a) The presence of the disease in children under 15 years old suggests active transmission focus and recent infection.

b) The presence of disability is the result of late diagnosis.

c) Early detection and prompt treatment of new cases is the strategy used in Brazil for endemic control.

d) Detection rate of new cases, rate of new cases in children younger than 15 years old, and cases with grade- 1 disability are among the main epidemiological indicators used in Brazil.

\section{Considering the characteristics of Mycobacterium leprae, it is} correct to state that:

a) PGL-1 has an antigenically specific trisaccharide in its plasma membrane.

b) Its genome has 4,411,529 bp and a guanine + cytosine content of $65.6 \%$.

c) It has 2,770 genes, with 1,604 genes encoding proteins and 1,116 pseudogenes, which shows a smaller genome compared to Mycobacterium tuberculosis.

d) It needs colder temperatures, between $30^{\circ} \mathrm{C}$ and $35^{\circ} \mathrm{C}$, to survive and proliferate.

4. Considering the genetic factors in leprosy, it is wrong to state that:

a) $\mathrm{MRC1}$ gene markers located in the $10 \mathrm{p} 13$ region are associated with reversal reaction.

b) Variations in PARK2 and PARCRG genes are associated with control of susceptibility to leprosy.

c) The $-308 \mathrm{~A}$ allele of the promoter region of the TNF gene seems to provide protection against leprosy.

d) Polymorphisms in the promoter genes for TNF-á and in the macrophage protein 1 associated with Nramp1 are associated with the development of MB forms.

5. Considering the genetic factors in leprosy, it is wrong to state that:

a) LTA +80 single nucleotide polymorphism is related to increased risk of leprosy in elderly populations.

b) Different alleles of the vitamin D receptor (VDR) gene are associated with tuberculoid and lepromatous leprosy.

c) HLA DR2 and DR3 alleles are associated with tuberculoid leprosy.

d) HLA DQ1 alleles are associated with lepromatous leprosy.

6. The in situ investigation of the phenotype of $T$ cells using immunohistochemical techniques with monoclonal antibodies in leprosy demonstrates:

a) Predominance of $\mathrm{T} \mathrm{CD} 4+$ population in lepromatous lesions.

b) CD4:CD8 ratio of 2:1 in tuberculoid lesions.

c) Prevalence of CD28+ cells in lepromatous lesions. d) CD4:CD8 ratio equal to the blood ratio in lepromatous lesions.

7. Regarding cytokines in leprosy skin lesions, choose the wrong statement:

a) High levels of IFN- , IL-2, and TNF- are produced by CD4+ clones in the tuberculoid form.

b) High levels of IL-4, IL-5, and IL-10 and low levels of IFNare produced by CD8+ clones in the lepromatous form.

c) There is increased TGF- $\beta$ in the lepromatous form.

d) There is production of IL-7 in the lepromatous lesion.

8. The following items are observed in leprosy reactions, except for:

a) Production of IL-1, TNF- $\alpha$, IL-2 and IFN- $\gamma$ cytokines in the lesions of type 1 reaction.

b) Increased IL-6, IL-8, and IL-10 in the lesions of erythema nodosum leprosum.

c) Increased TGF- $\beta$ in lesions of erythema nodosum leprosum.

d) High levels of TNF- $\alpha$ associated with low levels of IFN- $\gamma$ in the lesions of erythema nodosum leprosum.

9. According to the classification of the World Health Organization, it is incorrect to state that:

a) Patients with bacterial index lower than $2+$ are considered $\mathrm{PB} ; \mathrm{MB}$ patients are those with $\mathrm{BI}$ higher than or equal to $2+$.

b) Considering only clinical criteria, $\mathrm{PB}$ are the cases with up to five skin lesions and/or only one nerve trunk affected and $\mathrm{MB}$ are the cases with more than five skin lesions and/or more than one nerve trunk affected.

c) When skin smear is available, patients with positive results are considered $\mathrm{MB}$, regardless of the number of lesions.

d) All indeterminate, TT and BT patients are considered PB.

10. Certain clinical characteristics define the clinical forms of leprosy, and it is correct to state:

a) the indeterminate group is characterized by a small number of hypochromic spots, with slight decrease in sensitivity and only one nerve trunk affected.

b) In the TT form, there is a small number of asymmetric skin lesions, which are characterized by erythematous plaques, often with elevated external borders and hypochromic center, presenting significant change in sensitivity.

c) Hypochromic, erythematous or bright brownish spots with indefinite borders, generally asymmetric, and which may not have loss of sensation are typical of the LL form.

d) Erythematous plaques with fading outer borders, clear inner borders, and hypopigmented oval center are suggestive of the borderline form.

11. The following may be clinical manifestations of lepromatous leprosy, except for:

a) Nerve abscess.

b) Dry skin.

c) Lepromas.

d) Edema in the legs and feet.

12. Choose the statement that is not true for reversal reaction:

a) It is the result of delayed hypersensitivity.

b) It occurs in borderline patients.

c) It usually appears during treatment.

d) It usually is accompanied by systemic manifestations.

13. Considering the possible characteristics of skin lesions in type 1 reaction, choose the wrong option: 

a) Hyperesthesia.
b) Edema.
c) Scaling and ulceration.
d) Only two options are correct.

14. Regarding type 2 reaction, it is incorrect to state that:

a) There is deposition of immune complexes in the tissues.

b) It is manifested only by erythema nodosum in the skin.

c) Treatment is a triggering factor, but reaction can occur before or after it.

d) There is no immunological improvement in the outbreak.

15. The following are clinical manifestations that may occur in erythema nodosum leprosum, except for:

a) Symmetrically distributed subcutaneous inflammatory nodules.

b) Nodules only in the legs.

c) Ulcerations.

d) Fever, malaise, myalgia, edema, arthralgia, lymphadenomegaly, neuritis, hepatic and renal damage.

16. Considering silent neuritis in leprosy, it is incorrect to state that:

a) It is a deterioration of nerve function in the absence of nerve pain.

b) Invasion of nerve trunk by $\mathrm{M}$. leprae and reactions are pathological mechanisms.

c) Functional changes are usually minimal.

d) There may be hypoesthesia or anesthesia, paresis or paralysis, muscular weakness, and amyotrophy.

17. The following are aspects related to peripheral neuropathy of leprosy, except for:

a) It is a mixed neuropathy.

b) It can be considered a polyneuropathy.

c) Nerves may become thickened, irregular, and painful on palpation.

d) The most commonly affected nerves are: 5 th and 7th cranial nerve, median, radial, common fibular and tibial nerves.

18. Depending on the damaged nerve in leprosy, the following changes are expected, except for:

a) Orbicularis paralysis and lagophthalmos with or without ectropion in the lesion of the zygomatic branch.

b) Decreased sensitivity of the nose and cornea in the lesion of the trigeminal nerve.

c) Hyperextension of the metacarpophalangeal joint and flexion of the interphalangeal joints, especially of the 4 th and 5 th fingers in the ulnar nerve lesion.

d) Drop-wrist in the median nerve lesion.

19. Considering the location of sensitivity changes resulting from nerve impairment of the upper limbs in leprosy, it is incorrect to state that:

a) Radial nerve lesion: in the dorsal aspect of the thumb, third finger and radial portion of the fourth finger.

b) Median nerve lesion: in the palmar region, at the level of the thumb, index, middle fingers, and in the radial and volar half of the ring finger.

c) Advanced ulnar nerve lesion: in the inner edge of the hand and the 2 nd and 5 th fingers.

d) Ulnar nerve lesion: in the inner edge of the hand and the 4th and 5 th fingers.
20. The following are signs expected to be found in nerve lesions of the lower limbs:

a) Superficial fibular nerve: change in the sensitivity of the region above the first metatarsal space and hallux extension, other toes with dorsiflexion.

b) Deep fibular nerve: loss of sensitivity across the lateral and dorsal surface of the leg and change in the movements of eversion of the foot, side of the leg, and dorsum of the foot.

c) Superficial and deep branches of fibular nerve: foot drop and atrophy of the lateral and anterior parts of the leg.

d) Posterior tibial nerve: plantar anesthesia and paralysis of the intrinsic muscles of the foot, with claw toes, and hypertrophy of the plantar muscles.

Answer key

Acquired hyperpigmentations. An Bras

Dermatol. 2014;89(1):11-25.

$\begin{array}{llll}\text { 1) } \mathrm{A} & \text { 6) } \mathrm{C} & \text { 11) } \mathrm{D} & \text { 16) } \mathrm{A} \\ \text { 2) } \mathrm{C} & \text { 7) } \mathrm{C} & \text { 12) } \mathrm{C} & \text { 17) } \mathrm{B} \\ \text { 3) } \mathrm{C} & \text { 8) } \mathrm{B} & \text { 13) } \mathrm{C} & \text { 18) } \mathrm{A} \\ \text { 4) } \mathrm{D} & \text { 9) } \mathrm{D} & \text { 14) } \mathrm{D} & \text { 19) } \mathrm{B} \\ \text { 5) } \mathrm{D} & \text { 10) } \mathrm{C} & \text { 15) } \mathrm{D} & \text { 20) } \mathrm{B}\end{array}$

Papers

Information for all members: The EMC-D questionnaire is now available at the homepage of the Brazilian Annals of Dermatology: www.anaisdedermatologia.org.br. The deadline for completing the questionnaire is 30 days from the date of online publication. 